\title{
Sustentabilidade para Governança, Supremo Tribunal Federal e Conflito de Interesses
}

\author{
Sustainability for Governance, Brazilian Supreme Court \\ and Conflict of Interest
}

\section{Magno Federici Gomes}

Pontifícia Universidade Católica de Minas Gerais, Belo Horizonte - MG, Brasil

\author{
Bráulio Chagas Pighini \\ Universidade Presbiteriana Mackenzie, São Paulo - SP, Brasil
}

\begin{abstract}
Resumo: o presente estudo pretende abordar o tema conflito de interesses e a composição do Supremo Tribunal Federal (STF). Trata-se de pesquisa teórico-documental. $\mathrm{O}$ atual desenho constitucional de acesso aos cargos de ministros do STF, tendo como paradigma as regras de governança corporativa, não corresponde às melhores práticas, uma vez que permite prévias alianças políticas em prol daqueles que indicam os que irão decidir a constitucionalidade/legalidade das normas. A influência dominante dos Poderes Executivo e Legislativo na composição do Poder Judiciário caracteriza verdadeiras negociações, que não se comprometem com a própria independência do processo decisório e com a sustentabilidade.
\end{abstract}

Palavras-chave: Conflito de Interesses. Sustentabilidade para Governança Corporativa. Supremo Tribunal Federal.
Abstract: this paper intends to approach the theme involving the formation of the Brazilian Supreme Court (STF) and the conflict of interest. The method used for accomplishment this work was the theoretician-documentary. In that context the currently constitutional rules to form the STF, having as parameter the rules involving the good governance practices, seems not to comply to the principals of Corporate Governance. The creation of public alliances between the applicants to the Justice position with the Executive and Legislative branches implies in a relation known as conflict of interest, causing prejudices to the independence of judicial decisions and to the sustainable.

Keywords: Conflict of Interest. Sustainable for Corporate Governance. Brazilian Supreme Court.

Recebido em: 25/10/2015

Revisado em: 23/05/2016

Aprovado em: 30/05/2016 


\section{Introdução}

Ao se afastar o atual modelo de separação de poderes daquele definido por Montesquieu, ao Poder Judiciário não compete mais somente a resolução das questões de direito privado. Pelo contrário, o Poder Judiciário, na atual sistemática, vem ampliando o seu campo de influência ao exercer uma função política.

O modelo constitucional de composição dos ministros do Supremo Tribunal Federal (STF) envolve a discricionariedade do Chefe do Executivo e a aprovação do Senado Federal. A flagrante natureza política da nomeação daqueles que decidirão sobre a constitucionalidade das regras faz surgir a necessidade de responder se tal desenho constitucional está de acordo com as melhores práticas da denominada governança corporativa. A imparcialidade e a independência, garantias processuais da Constituição da República de 1988 (CR/1988) e do Código de Processo Civil (CPC), são prejudicadas em função da natureza política de nomeação dos ministros do STF? De alguma maneira configura-se o conflito de interesses na nomeação e aprovação dos candidatos a ministros do STF? Dentro das denominadas melhores práticas, tal desenho constitucional de nomeação atenderia aos princípios de governança e sustentabilidade?

O objetivo do trabalho, dando continuidade à discussão do tema: estrutura de governança, conflito de interesses e desenvolvimento sustentável judicial (no qual se demonstrou que o atual sistema brasileiro, além de incentivar o conflito de interesses, não possui instrumentos hábeis a preveni-los e solucioná-los), consiste em, justamente, comprovar a hipótese: se os princípios de governança corporativa e sustentabilidade se aplicam quando da nomeação e aprovação dos candidatos a ministros do STF.

Nesse contexto, para a realização do trabalho, foi utilizada a metodologia teórico-documental, sendo analisadas obras de referência para o estudo do direito, em especial diversas teses e dissertações das mais respeitadas instituições de ensino que analisaram em profundidade a temática da nomeação dos ministros do STF, bem como obras de referência sobre governança corporativa e conflito de interesses. 
O trabalho está dividido em duas partes, iniciando-se pelo estudo da composição do STF, analisando o processo de sabatina dos candidatos a ministros, quando será realizada uma breve dissertação sobre a politização dos tribunais superiores, visando demonstrar por meio de dados empíricos a forte influência dos Poderes Executivo e Legislativo na composição dos órgãos de cúpula do Poder Judiciário. Finalmente, será delineada a conclusão do trabalho.

\section{O Supremo Tribunal Federal e a sua Composição Jurídica/ Política}

É importante transcrever a razão de o presente estudo adotar como paradigma o STF. Além dos motivos óbvios de hierarquia, uma vez que o STF é órgão de cúpula do Poder Judiciário brasileiro, atualmente, tendo em vista a grave crise política que assola o Brasil, o caso do "Petrolão", muito, ainda hoje, se discute sobre a influência política na composição do STF, chegando ao ponto de o ministro Gilmar Mendes afirmar que o $\mathrm{STF}$, dentro de alguns anos, se tornaria uma corte bolivariana ${ }^{1}$. Em um relacionamento de poder, conforme se demonstrou na primeira parte deste trabalho, quanto maior for o número de "aprovadores", menores serão as forças de resistência. Ao se Exemplificar a necessidade de uma corte majoritária, tem-se, dentre vários exemplos, a Lei das Ações Direta de Inconstitucionalidade e Declaratória de Constitucionalidade (LADI), instituída pela Lei n. 9.868/1999, que apesar de seu efeito erga omnes, possui um rol de legitimidade ativa reduzido e não admite intervenção de terceiros (artigo $2^{\circ}$ e artigo 18 da LADI). Tal limitação reduz drasticamente o poder de impugnação das partes prejudicadas e ainda, sendo proposta diretamente no STF, com composição majoritária, garante, ao menos no campo da lógica, a eficácia das intenções.

Com isso, o ato de compor o STF, importa em reduzir as forças da oposição (para não afirmar a sua própria extinção), sendo um elemento importante nas questões de governabilidade. Nesse contexto, o estudo de como funciona o procedimento de aprovação de um ministro do STF torna-se essencial.

${ }^{1}$ Ver Motta (2014). 
A nomeação dos ministros do STF sempre obedeceu aos ditames da ordem pública. Os Presidentes da República, antes do denominado "Estado Novo", sempre tiveram predileção pelos chefes de polícia (BALEEIRO, 1968 apud DAMASCENO, 2005, p. 126). Tal predileção denota a natureza autoritária e do coronelismo que imperava no Brasil, durante a Primeira República ${ }^{2}$. O viés político envolvendo a nomeação dos ministros do STF sempre foi objeto de discussão entre aqueles que se mantém no poder, bem como daqueles que estão fora. A suposta irresignação daqueles que hoje vêm como certa uma "bolivarização" do $\mathrm{STF}$, também já se valeram de tais dispositivos. O ex-presidente Fernando Henrique Cardoso nomeou o seu ex-ministro da Justiça, Nelson Jobim, bem como o "seu"3 Advogado Geral da União, o atual, ministro Gilmar Mendes. Portanto, mais do que evidente, a despeito dos critérios objetivos da CR/1988, que as nomeações aos cargos do STF vinculam-se, em sua maneira própria, aos efeitos do filhotismo (LEAL, 1997, p. 40-41). Tal efeito tem como consequência que quanto mais se aproxima o candidato ao cargo de ministro do STF, menos este depende de sua qualificação e independência (elementos que fomentaram a sua subida e destacamento profissional $)^{4}$.

A despeito do notável saber jurídico, requisito constitucional, o que se verifica não é a notoriedade da sabedoria jurídica do candidato a mi-

\footnotetext{
${ }^{2}$ E mais, nos dizeres de Leal (1997) acerca da relevância do papel da polícia na República Velha: "[...] durante a Primeira República, a organização policial foi um dos mais sólidos sustentáculos do 'coronelismo' e, ainda hoje, em menores proporções, continua a desempenhar essa missão" (LEAL, 1997, p. 226).

${ }^{3}$ A expressão "seu” encontra-se no sentido de que o Advogado Geral da União é de livre nomeação (escolha) do Presidente da República, nos termos da Lei Complementar de n. 73/1995: "Art. 3. A Advocacia-Geral da União tem por chefe o Advogado-Geral da União, de livre nomeação pelo Presidente da República, dentre cidadãos maiores de trinta e cinco anos, de notável saber jurídico e reputação ilibada." (BRASIL, 1995, art. 3º).

${ }^{4}$ De acordo com Speck (2002) tem-se que: “[...] ao chegar no topo da hierarquia do Poder Judiciário, a exigência em relação à pré-qualificação profissional mude consideravelmente. Enquanto os magistrados de primeiro grau são todos recrutados por concurso, os Tribunais de Justiça e Tribunais Superiores têm um quinto de recrutamento externo. No Superior Tribunal de Justiça, esse número sobe para um terço e, no caso do Supremo Tribunal Federal, não há mais nenhuma exclusividade do magistrado de carreira para as vagas" (SPECK, 2002, p. 271).
} 
nistro, mas sim, a notoriedade de suas decisões e relacionamentos. Tais disposições (ou na melhor leitura, das pré-disposições) políticas também se aplicam ao quinto constitucional. A inserção do nome junto às listas decorre, além de destacada trajetória profissional, de uma estreita vinculação política. Terminando, por fim, essa via relacional no Poder Executivo (Estadual ou Federal), o que torna ainda mais politizada a nomeação ao cargo de ministro e desembargador.

Ciente de tal contexto, novamente o CNJ, através da Resolução n. 106/2010, buscou trazer objetividade ao processo de promoção dos magistrados junto aos seus respectivos tribunais. Pois bem, como se demonstrou, a nomeação para o cargo de ministro do STF constitui em "[...] lobbies de diversos setores, envolvendo políticos, juristas e até mesmo associações como a Associação dos Magistrados do Brasil (AMB), Associação dos Juízes Federais do Brasil (Ajufe)" (OLIVEIRA, 2011, p. 24)5. Tal situação não é despercebida por alguns ministros dos tribunais superiores, como bem ressaltou a ministra do STJ, Eliana Calmon, em entrevista concedida ao jornalista Recondo $(2009)^{6}$. Tal ingerência mesmo que

${ }^{5}$ Corrobora a afirmação Oliveira (2011): "Nesse sentido, conta que o jornal Correio Braziliense publicou, em maio de 2003, declaração do ministro da justiça, Márcio Thomaz Bastos, "de que as três (primeiras) nomeações feitas pelo presidente Lula ao STF (Joaquim Barbosa, Cezar Peluso e Ayres Britto) levaram em conta a afinidade dos escolhidos com as propostas do governo que tramitavam no Congresso nacional, em especial a reforma do Judiciário". Ao analisar a nomeação de Lewandowski aduz que os diversos lobbies resultaram: na confecção de uma lista com 11 nomes encaminhada pelo ministro da justiça, Thomaz Bastos, ao presidente Lula. Foi aventada a possibilidade da indicação de um nome ligado à cúpula do PT [...], mas ante a possibilidade de resistência do Senado esses nomes foram deixados de lado. [...] De acordo com notícias veiculadas na mídia, o presidente Lula teria conversado pessoalmente com três dos candidatos ao Supremo antes de fazer a indicação, Lewandowski, [...], Misabel de Abreu Machado Derzi [...] e Luiz Edson Fachin [...]. Ao ser indagado em entrevista ao site Consultor Jurídico ('Idéias do Escolhido', 2006), o futuro ministro afirmou: 'Eu integrei a lista de 11 ilustres nomes [...]. Acredito que a ideia do presidente Lula foi escolher um nome técnico." [...] O ministro Márcio Thomaz Bastos costuma ter um papel muito importante nas escolhas e acho que ele teve nesta. Foi conselheiro da OAB paulista e conheço o Márcio há muitos anos."” (OLIVEIRA, 2011, p. 172).

${ }^{6}$ Ao responder a pergunta acerca da existência de um grupo formado no STJ para decidir as indicações, à Ministra Eliana Calmon, assim respondeu: "Sim. Existe um grupo com liderança forte que patrocina a eleição de pessoas amigas, de candidatos que lhes são 
indireta (o que torna mais perniciosa, uma vez que clandestina) importa em prejuízo ao princípio constitucional da separação de poderes. A independência arrolada na CR/1988 tem como significado que a investidura e a permanência nos Poderes da República independem da vontade dos outros, bem como o exercício de suas prerrogativas. Seguindo as lições de Silva (2011), o conceito de harmonia está adstrito ao respeito de cada poder no campo de incidência do outro, uma vez todos, à sua maneira, buscam o bem comum (SILVA, 2011, p. 109-111).

Nenhum princípio é absoluto, mesmo os constitucionais ${ }^{7}$. A despeito da limitação constitucional das competências dos poderes, comumente verifica-se a ingerência de um nos outros, quando da edição de medidas provisórias (Poder Executivo em face do Poder Legislativo); quando da declaração de inconstitucionalidade de uma lei (Poder Judiciário em face do Poder Legislativo); quando do julgamento nos casos dos crimes de responsabilidade pelo Poder Legislativo (Poder Legislativo em face do Poder Judiciário) e etc. Nesse sentido, indene de dúvidas de que o STF sempre conviveu (o que muda é a intensidade) com a intervenção do Poder Executivo e do Poder Legislativo. Citando exemplos, tem-se Floriano Peixoto ${ }^{8}$ que ao deixar de nomear vários ministros para a composição do STF, impediu a instalação de quórum mínimo, chegou-se até mesmo ao ponto de ser editada norma constitucional que vinculava a eficácia das decisões do STF à deliberação dos Poderes Legislativo e Executivo9 . A CR/1988, apesar de

simpáticos, de tal forma que as listas são feitas fechadas, ou seja, os três nomes que são indicados já são conhecidos antes da votação. Eu já sabia os três nomes que iam se sagrar nessa ultima eleição" (RECONDO, 2009).

7 "Pois, sabe-se, que os direitos fundamentais não são absolutos e ilimitados, encontrando seus limites em outros direitos fundamentais, também consagrados pela Magna Carta" (CAMPOS, 2004, p. 24).

${ }^{8}$ Apenas para ressaltar a contemporaneidade das condutas realizadas, cita-se matéria publicada no jornal Valor Econômico, com o título Cadeira Vazia causa adiamento de julgamentos no Supremo (MENGARDO, 2015).

9 “Art. 96 da Constituição de 1937. Só por maioria absoluta de votos da totalidade dos seus Juízes poderão os Tribunais declarar a inconstitucionalidade de lei ou de ato do Presidente da República. Parágrafo único - No caso de ser declarada a inconstitucionalidade de uma lei que, a juízo do Presidente da República, seja necessária ao bem-estar do povo, à promoção ou defesa de interesse nacional de alta monta, poderá o Presidente da República 
não conferir aos demais Poderes tal prerrogativa, manteve a influência dos Poderes Executivo e Legislativo na escolha dos ministros ${ }^{10}$.

Expostas tais ilações, passa-se à análise do procedimento de escolha dos candidatos a ministros do STF, quando de sua indicação pelo chefe do Poder Executivo. A nomeação dos ministros é definida por Cretella Júnior (1992, p. 3.063) como ato administrativo complexo e discricionário, complexo pelo fato de envolver dois Poderes, o Executivo (na pessoa do Presidente da República) e o Legislativo (na pessoa do Senado) e discricionário, pois compete exclusivamente ao Presidente da República a escolha do candidato. O modelo adotado pelo Brasil é justificado pelo objetivo de proporcionar segurança e legitimidade ao STF (MORAES, 2000, p. 77). Portanto, essa complexidade confere ao procedimento um controle dos poderes e a concentração deles.

A despeito de toda a natureza política envolvendo a nomeação de um candidato a ministro do STF, o procedimento, ao menos, deve respeitar as garantias constitucionais (artigo 37 da CR/1988). Paes (2011) realizou significante trabalho acerca das influências políticas envolvendo a nomeação dos ministros do STF, fazendo um comparativo com o sistema americano (sistema este adotado no Brasil), Paes (2011) informa que, apesar da indicação do candidato à Justice ser realizada pelo Presidente da República, somente após o aval da Comissão de Justiça americana é que ele é remetido à aprovação do Senado, sendo o candidato duramente

submetê-la novamente ao exame do Parlamento: se este a confirmar por dois terços de votos em cada uma das Câmaras, ficará sem efeito a decisão do Tribunal" (BRASIL, 1937, art. 96).

${ }^{10}$ Tais preocupações foram levantadas por Schwartz (1955) quando apresenta a sua crítica ao critério de nomeação dos Justices americanos: "No sistema judiciário federal, por outro lado, não se pode negar que as considerações políticas ainda desempenham um papel fundamental na escolha dos membros da magistratura. Assim, para tomar o mais alto tribunal da nação como exemplo, no início de 1953, após vinte anos de governo democrata, a Corte Suprema se compunha de oito democratas e um republicano. E, dos oito pertencentes ao partido no poder, cinco eram membros ativos do Governo na época de sua elevação à Corte Suprema. A tendência de nomear esses elementos ativos do Governo para altos cargos da magistratura - e há uma tendência semelhante nos tribunais federais inferiores - é uma prática que tem sido muito deplorada pelos juristas americanos" (SCHWARTZ, 1955, p. 169). 
arguido. A arguição que pode durar de um a 122 dias, sendo que ocorreram 27 rejeições dos nomes indicados, destas 59\% ocorreram em um Senado contrário ao Governo quando, lado outro, um correspondente a 90\% (noventa por cento) de aprovação chegou a ser alcançado quando o Senado foi pró-Governo (PAES, 2011, p. 48-49).

No procedimento da sabatina brasileiro, são os parlamentares que ganham notoriedade, na medida em que vão proferir suas manifestações contrárias ou favoráveis à indicação do Presidente da República para aquele que desempenhará o importante papel no processo de decisão de constitucionalidade das leis. À Comissão de Constituição, Justiça e Cidadania (CCJ), conforme o inciso III do artigo 72 do Regimento Interno do Senado Federal (RISF), é imbuída o ônus de prover a sabatina. O artigo 383 do RISF traz as normas a serem observadas durante o procedimento e prevê, no inciso VI, que a reunião será pública e a votação secreta, vedando qualquer declaração ou justificação de voto. Paes (2011) conferindo profundidade ao tema e ao analisar os procedimentos da sabatina, encontrou importantes dados, abaixo representados:

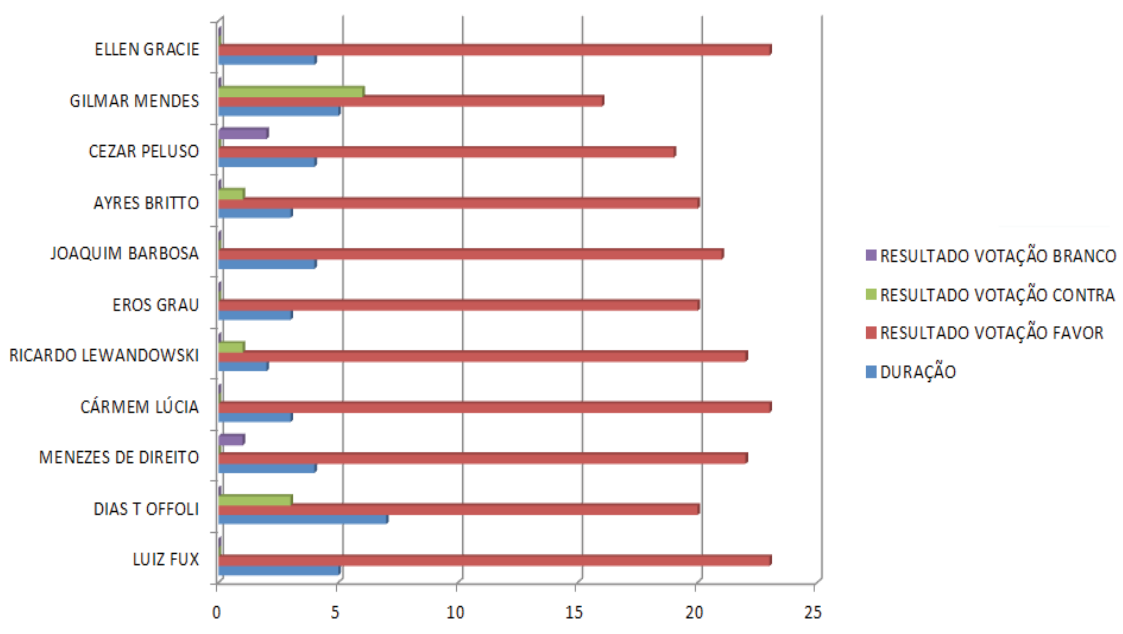

Gráfico 1: Resultado da votação - CCJ (2011)

Fonte: Paes ( 2011, p. 66) 
Como bem representado, tendo como contrapartida a duração dos procedimentos de sabatina dos Justices, e a despeito de algumas sabatinas terem se alongado por mais de cinco horas, o que se percebe na prática é uma natureza peculiar dos Parlamentares em promover verdadeiros discursos de contemplação em favor dos candidatos. Paes (2011, p. 70) chega a citar o ex-senador Antonio Carlos Magalhães quando da sabatina do ex-ministro do STF, Joaquim Barbosa. Ao partir desse paradigma, percebe-se que, de fato, a arguição não é uma práxis por parte dos parlamentares (PAES, 2011, p. 68-69).

Ainda, tendo em vista os "discursos de contemplação"11, o voto que por via de regra, deveria ser secreto, torna-se um verdadeiro discurso de boas vindas. Contudo, conforme constatou Paes (2011, p. 65), a filiação partidária, seja do candidato a ministro, seja da composiçaõ do CCJ, diferentemente do que ocorre nos Estados Unidos, pouco ou nada influi no procedimento de sabatina. Verifica-se, na verdade, uma verdadeira omissão por parte dos senadores em de fato prover a arguição, já que as perguntas aos candidatos dão lugar aos elogios. Assim, é

[...] possível afirmar que o processo de escolha é eminentemente político, não no sentido partidário, mas no sentido de que os senadores não se indispõem, não divergem, mostrando satisfação de ali estarem votando favoravelmente à indicação do Presidente da República. (PAES, 2011, p. 76)

Portanto, não soa estranha a discussão cada vez mais envolvendo uma possibilidade de emendar a CR/1988 no intuito de alterar as regras de nomeação dos ministros do $\mathrm{STF}^{12}$. Tais regras estão longe de propor a

\footnotetext{
${ }^{11}$ Importante consignar a manifestação do senador José Eduardo Dutra, do PT, quando da sabatina do ministro Gilmar Mendes: “[...] eu disse que lamento que o Senado continue adotando essa postura de tratar sabatinas para a indicação de autoridades como mera formalidade a ser cumprida. Essa é a minha opinião, que mantenho. E V. Exa , como qualquer senador, tem o direito de discordar dela, mas não tem o direito de admitir ou deixar de admitir o que eu digo.” (PAES, 2011, p. 72).

12 Dentre os Projetos de Emenda para a Constituição (PEC), indicados por Machado (2011, p. 41-45) estão tramitando somente a PEC n. 473, de 2001, do Sr. Antonio Carlos Pannunzio e a PEC n. 566, de 2002, do Sr. Alceu Collares (MACHADO, 2007, p. 41-45).
} 
nomeação aos cargos de ministros, conforme a Suprema Corte Britânica, mantendo a natureza política de nomeação, o que confere a todo o procedimento a peculiaridade de um jogo de "cartas marcadas".

\section{A Politização dos Tribunais Superiores}

Decorridos todos os argumentos até o momento expostos, chega-se à uma conclusão de que, além de óbvia, é de extrema importância: existe uma politização do Poder Judiciário, bem como existe uma judicialização da política ${ }^{13}$. Nesse contexto, Araújo (2004), citada por Damasceno (2005, p. 150), declara que com o advento do Estado do Bem-Estar social ${ }^{14}$, instaurou-se uma crise na separação dos poderes, onde a discricionariedade do Poder Judiciário acabou por transformá-lo em legislador implícito. Esta capacidade de legislar (Judicial Review), mesmo que de forma negativa, implica uma atuação positiva que em conformidade com a CR/1988, transforma as decisões judiciais em verdadeiras legislações e dotadas de eficácia. No mesmo ato, a decisão judicial legisla e executa (avocando os Poderes Legislativo e Executivo).

Nesse sentido, a separação heterogênea dos Poderes da República é marginalizada, dando espaço para uma função política do Estado ${ }^{15}$.

13 Assim: “[...] é nesse cenário de ‘tirania da maioria’ que a sociedade acabou por se
encontrar com a vontade do legislador constituinte, a que não faltou, nos primeiros
anos da nova Carta, a ação do Ministério Público. Facultado o controles abstrato da
constitucionalidade das normas à comunidade dos interpretes - e, nela, ao que havia
de organizado na sociedade civil, o Poder judiciário começa a ser percebido como mais
um estatuário para as insatisfações existentes com o ativismo legislativo do Executivo,
sendo convocado ao exercício de papéis constitucionais que o identificam como o guardiã
odos valores fundamentais [...] é da presença desse novo processo institucional que tem
derivado, no Brasil, a chamada judicialização da política, fenômeno corrente nos países
de democracia avançada como Alemanha, Itália, França Inglaterra e EUA." (VIANNA,
1999 apud DAMASCENO, 2005, p. 65).
14 Em sentido equivalente: “[...] o desenvolvimento dos Estados Democráticos e
suas políticas de bem-estar social forçaram mudanças na engenharia institucional e a
transformação do Judiciário em poder ativo." (SADEK, 2002 apud DAMASCENO,
2005 , p. 50).
15 Conforme: “[...] a função política do Estado é a atividade que órgãos instituídos pela
Constituição exercem no âmbito de sua competência, tendo por objetivo preservar a 
Kelsen, citado por Paixão (2007, p. 64), afirma que o Poder Judiciário teria a prerrogativa de apenas aplicar o direito, sendo o exercício da função política por parte dos tribunais, uma exceção à regra que ocorre quando o tribunal declara inconstitucional uma lei, regramento, ou quando estabelece um precedente. À margem de toda essa discussão o que se pode afirmar, é que toda a decisão proferida pelo STF exerce uma forte função política. Tal afirmativa é positivada pela própria leitura do CPC ao exigir das partes o cumprimento do requisito da Repercussão Geral nos Recursos Extraordinários (BRASIL, 1973, art. 543-A, § 1º do CPC).

Toda função política deve ser contextualizada e mantendo-se à temática do presente trabalho, opta-se em analisar a influência dessa função sob a égide da CR $/ 1988^{16}$, que saída de um período de intervencionismo e

sociedade política e promover o bem comum, e que consiste em determinar, mediante a livre interpretação de normas constitucionais, o que é o interesse público e quais são os meios necessários à sua implementação.” (PAIXÃO, 2007, p. 51).

${ }_{16}$ Para um maior aprofundamento do tema, sugere-se a leitura do trabalho: A Função Política do Supremo Tribunal Federal de Paixão (2007). Segundo o autor (2007), a divisão da história do STF pode ser realizada em sete fases: "1) Fase inicial (19811987), que constitui um período de hesitação, em que o Supremo Tribunal Federal ainda estava em busca de seu papel institucional na República recém proclamada. Foi um período marcado por atritos e desgastes com dois Presidentes da República (Floriano Peixoto e, em menor dimensão, Prudente de Moraes), bem como pela produção de uma jurisprudência conservadora, por vezes até reacionária. Foi um período marcado também por uma grande instabilidade na composição do Tribunal (39 ministros nomeados em seis anos). 2) Fase de ampliação do papel institucional (1897-1926), quando o Supremo ocupou, pouco a pouco, o espaço que lhe havia sido reservado pela Constituição de 1891 e se valeu de uma interpretação ampliativa do instituto do habeas corpus para suprir a falta de norma processual que amparasse direitos necessitados de proteção urgente. Também foi um período de maior estabilidade na composição do Tribunal, durante o qual passaram por ele alguns de seus integrantes mais marcantes. 3) Fase de contenção imposta (1926-1945), que foi um período durante o qual vários setores políticos entenderam que o Supremo Tribunal Federal tinha "ido longe demais" e procuraram refrear sua capacidade de exercer função política. Este período teve início com a limitação do alcance do habeas corpus, a partir de uma nova redação dada à Constituição de 1891 por emenda promulgada em 1926, e prosseguiu como decorrência da Revolução de 1930. Foi um período durante o qual diversos atentados contra a independência do Supremo Tribunal Federal foram cometidos. 4) Fase de contenção voluntária (1945 - 1964), período em que o Supremo Tribunal Federal recobrou suas prerrogativas, mas inovou pouco na seara política. Não por falta de oportunidade, ou por algumas limitação, mas porque, de um 
autoritarismo, estipulou e ampliou diversas prerrogativas aos Poderes da República $^{17}$. Dessa forma, a:

[...] rigidez da separação de Poderes no sistema presidencialista potencializa a necessidade de um árbitro nos conflitos frequentes entre Executivo e Legislativo e no controle constitucional dos atos destes dois Poderes, se, por um lado, o STF adquire iminência mais pronunciada neste sistema político, por ser o agente mais qualificado para arbitrar estes conflitos e salvaguardar a Constituição, por outro ele não está sozinho nesta tarefa. Juntam-se a ele todos os juízes e tribunais do país, pelo modo difuso-incidental de controle constitucional das leis e demais atos normativos. (ARANTES apud PAIXÃO, 2007, p. 211) ${ }^{18}$

modo geral, estando de acordo com as orientações postas pelos outros ramos do poder, optou por confirmá-las. 5) Fase de enfrentamento (1964 - 1968), quando o Supremo Tribunal Federal - apesar de uma nova série de atentados à sua independência, por meio dos Atos Institucionais do Regime Militar iniciado em 1964 - procurou fazer com que a Constituição e a legislação vigente fossem observadas e, para isso invalidou diversos atos do governo federal. 6) Fase de esvaziamento da competência (1968-11988), período marcado pelo pouco espaço jurídico remanescente para que o Supremo Tribunal Federal exercesse função política. 7) Fase de retomada do exercício das funções políticas, a partir da entrada em vigor da Constituição de 1988, e da consequente ampliação do papel do Poder Judiciário como um todo e do Supremo Tribunal Federal em particular.” (PAIXÃO, 2007, p. 113-114).

${ }^{17}$ Desse modo: “[...] a Constituição Federal de 1988 introduziu no ordenamento jurídico brasileiro diversos institutos, entre os quais a iniciativa popular para apresentação de projeto de lei, [...] o mandado de injunção, a arguição de descumprimento de preceito fundamental e o estado de defesa. Posteriormente, emendas constitucionais introduziram outras novidades, tais como a ação declaratória de constitucionalidade e a possibilidade de reeleição, para o período subsequente, de ocupantes de cargos eletivos do Poder Executivo. Especialmente em relação ao Poder Judiciário, a Constituição de 1988 tem disposições de suma importância, algumas das quais inovadoras? A extinção do Tribunal Federal de Recursos, acompanhada da criação do Superior Tribunal de Justiça e dos Tribunais Regionais Federais, a inafastabilidade do controle judicial (art. 5 XXXV), e ainda a ampliação dos mecanismos de controle de constitucionalidade.” (PAIXÃO, 2007, p. 204).

18 Ademais, segundo Paixão (2007): “Outro fator da maior relevância para assegurar a legitimidade do Supremo Tribunal Federal para exercer função política é o modo de escolha de seus integrantes. A Constituição determina que eles devem ser nomeados pelo Presidente da República, depois de seu nome ter sido aprovado pelo Senado Federal. 
Portanto, o conceito frio de separação de poderes de Montesquieu não encontra mais guarida na atual evolução da sociedade brasileira. O Poder Judiciário passa a ter um papel de coadjuvante na implantação e implementação de políticas públicas. Nesse sentido, toda vez que ao magistrado é requerida uma decisão, esta é pró-futuro, conferindo, por muitas vezes, às normas programáticas, eficácia presente e com isso dando vida à $\mathrm{CR} / 1988$ que deixou de ser apenas uma carta de intenções, pois a "Constituição deve prevalecer sobre a lei ordinária, a intenção do povo sobre a de seus agentes" (HAMILTON, 2005, p. 472). Verifica-se que o fenômeno da judicialização da política, que teve início com o caso Marbury vs Madison (DAMASCENO, 2005, p. 70), trouxe ao Poder Judiciário, seja em última ou única instância, a competência para dirimir as questões constitucionais e por via de regra, a palavra final sobre a validade dos atos emanados pelos demais poderes, conferindo às decisões do STF uma natureza dupla (jurídica e política).

A independência (artigo 35, inciso I, da LOM), elemento característico dos juízes de primeira instância (SPECK, 2002, p. 270) é dissipada nas instâncias superiores, tendo em vista, a natureza política dos órgãos de cúpula, em função do poder administrativo dos presidentes dos Tribunais de Justiças às promoções e a possibilidade de remoção dos magistrados. A despeito da garantia constitucional à inamovibilidade ${ }^{19}$, tem-se que tal garantia está condicionada ao "motivo de interesse público" (artigo 95, inciso II, da CR/1988). Ademais, a visibilidade no meio político é

Deste modo, embora os ministros não sejam eleitos pelo voto popular, indiretamente sua escolha é feita pelo povo, por meio de seus representantes eleitos. Em função dessa participação dos representantes eleitos, o perfil dos nomeados para a o Supremo Tribunal Federal tende a reproduzir, embora de forma simplificada e imperfeita, o perfil do eleitorado. Ao longo de sua história a Corte tem recebido cidadãos de diferentes origens, e com diferentes experiências profissionais anteriores ao ingresso no Supremo Tribunal Federal. E mais recentemente a presença feminina das Ministras Ellen Gracie e Cármem Lúcia tem contribuído para tornar a composição ainda mais representativa." (PAIXÃO, 2007, p. 230).

${ }^{19}$ Ao ressaltar a relatividade desta garantia constitucional, a inamovibilidade, seguem os argumentos de Leal (1997): “[...] as garantias legais nem sempre podem suplantar as fraquezas humanas: transferência para lugares mais confortáveis, acesso aos graus superiores, colocação de parentes, gosto do prestígio, eis os principais fatores da predisposição política de muitos juízes.” (LEAL, 1997, p. 243). 
um fator que favorece muito mais as devidas promoções do que a atuação nas comarcas ${ }^{20}$. Essa junção política/jurídica, de certa forma, induz o magistrado a prolatar as suas decisões de forma a favorecer certos interesses. Os interesses políticos dos magistrados, cuja classe força em negar a sua existência, retira de certa forma, a possibilidade dos demais operadores do direito em uma previsibilidade das decisões a serem proferidas. Ao contrário do que ocorre na Suprema Corte Americana, seus integrantes explicitam em suas decisões, o conjunto de seus valores, embasando-as de forma coerente com as suas convicções e militâncias políticas (BALEEIRO, 1972 apud DAMASCENO, 2005, p. 142).

Portanto, tem-se uma relação muito íntima entre política e direito, fugindo-se de qualquer forma de eufemismo, uma vez que o processo de promoção aos candidatos a ministros e desembargadores é um procedimento político/jurídico complexo ${ }^{21}$.

20 "Uma brilhante carreira de juiz não se faz - ou raramente - em jurisdição, mas através de passagens pelo Ministério da Justiça, ou de uma requisição par outra administração, até pela passagem - via nobre - por um gabinete ministerial. A maioria dos chefes de jurisdições importantes também passou por tais aceleradores de carreira. É paradoxal ver um corpo de juízes manter um certo desdém, mais ou menos disfarçado, a respeito da jurisdição que é, no entanto, sua razão de ser. 'Todo o tempo passado em jurisdição é perdido para a carreira', é o que os juízes se aprazem em dizer. Hoje se constata, na França, que a afiliação política é melhor e em breve tempo remunerada que o profissionalismo." (GARAPON, 2001, p. 63). Ademais, importante consignar as lições de Maccalóz (2002), p. 28: “As nomeações e as promoções são comandadas por interesses familiares, econômicos e partidários, principalmente nos tribunais superiores. Mesmo quando o candidato tem méritos pessoais, só consegue a nomeação se cumprir o "rito" das negociações."

${ }^{21}$ Nesse contexto, Fernandes (2013) citando trabalho de Almeida (2010) e Silveira (2012) traçou a trajetória dos ministros do STF, antes de seu ingresso na Suprema Corte brasileira, assim verifica-se que: "[...] de 1985 a 2008, 50\% dos ministros do STF exerceram cargos políticos no Executivo ou no Legislativo antes de sua indicação. Em outra pesquisa, notase que $66,66 \%$ dos ministros nomeados (14 de um total de 21) de 1988 até março de 2012 exerceram alguma atividade política prévia, seja no Executivo, seja no Legislativo. O contato dos ministros com a política partidária antes de sua nomeação também é significativa no período de 1985 a 2008: 40\% dos ministros do STF exerceram lideranças associativas ou coorporativas" (ALMEIDA, 2010; SILVEIRA, 2012 apud FERNANDES, 2013, p. 182). 
A presença dos ministros no campo da política seja partidária, ou não, tendo em vista a função política do STF, não demonstra incongruência com o sistema democrático. Contudo, a ingerência dos Poderes Executivo e Legislativo configura predileções a favor dos candidatos mais ajustáveis. Desse modo, nos dizeres de Leal (1999 apud MACHADO, 2007 , p. 45), a realidade tem demonstrado que as regras próprias do direito não têm prevalecido nas decisões judiciais, razão pela qual o autor citado aduz que o controle externo da magistratura e a aplicação das súmulas vinculantes vêm ganhando espaço ${ }^{22}$.

Contudo, indene de dúvidas de que o poder exercido pelo STF, ao proferir suas decisões, gera impactos não apenas na sociedade, mas sim, nos demais Poderes, sendo assim lícita a intervenção dos demais, representando o verdadeiro sistema de check and balances. Escreve Pekelis (1970 apud CAPPELLETTI, 1999, p. 53) que

[...] uma atividade legislativa ou administrativa eficaz de modo algum é incompatível com o controle judiciário da própria atividade, [...] antes a coexistência equilibrada de tal atividade e de seu controle representa a essência mesma do regime constitucional.

Dessa forma o rigor na exclusiva separação dos poderes, como até antes havia defendido Montesquieu, destinaria o Poder Judiciário somente aos conflitos advindos da vida privada (CAPELLETTI, 1999, p. 53) ${ }^{23}$. Portanto, a influência dos demais poderes na composição dos tribunais constitucionais, não é de toda maléfica, uma vez que necessária ${ }^{24}$.

\footnotetext{
${ }^{22}$ Afirmação esta que diverge do entendimento adotado nesse estudo.

${ }^{23}$ Apenas ressaltando que para Cappelleti (1999): “[...] a verdade é que apenas um sistema equilibrado de controles recíprocos pode, sem perigo para a liberdade, fazer coexistir um legislativo forte com um executivo forte e um judiciário forte. Justamente este equilíbrio de forças, de contrapesos e controles recíprocos, constitui o grande segredo do inegável sucesso do sistema constitucional americano.” (CAPPELLETI, 1999, p. 54).

${ }^{24}$ Nesse sentido, Tavares Filho (2006): "Essa necessidade deflui, de maneira natural, do cenário jus-político das Cortes Constitucionais, em razão, exatamente, da própria natureza desses órgãos: ora desempenham função como cortes constitucionais explícitas, desvinculadas do Poder Judiciário (a exemplo das Cortes Constitucionais europeias); ora fazem coexistir em seu âmago as funções de Tribunais Constitucionais de última
} 
O fenômeno da judicialização (no qual coube ao Poder Judiciário decidir as questões sociais, políticas e morais) coloca o Poder Judiciário, sob certa perspectiva, em ponto mais elevado. Cumpriu e compete aos tribunais e ao STF a decisão de questões eminentemente políticas, sociais ou morais ${ }^{25}$. Tal protagonismo gerou sérias críticas ao Poder Judiciário, conforme leciona Barroso $(2012)^{26}$, assim, os argumentos apesar de per-

instância, localizados no ápice do Poder Judiciário do país, com as atribuições de Cortes Constitucionais, propriamente ditas (definição na qual se encaixam o Brasil e os Estados Unidos) (TAVARES FILHO, 2006, p. 19).

${ }^{25}$ Nos dizeres de Barroso (2012): “[...] como consequência, quase todas as questões de relevância política, social ou moral foram discutidas ou já estão postas em sede judicial, especialmente perante o Supremo Tribunal Federal. A enunciação que se segue, meramente exemplificativa, serve como boa ilustração dos temas judicializados: (i) instituição de contribuição dos inativos na Reforma da Previdência (ADI 3105/DF); (ii) criação do Conselho Nacional de Justiça na Reforma do Judiciário (ADI 3367); (iii) pesquisas com células-tronco embrionárias (ADI 3510/DF); (iv) liberdade de expressão e racismo (HC 82424/RS - caso Ellwanger); (v) interrupção da gestação de fetos anencefálicos (ADPF 54/DF); (vi) restrição ao uso de algemas (HC 91952/SP e Súmula Vinculante $\mathrm{n}^{\mathrm{o}}$ 11); (vii) demarcação da reserva indígena Raposa Serra do Sol (Pet 3388/RR); (viii) legitimidade de ações afirmativas e quotas sociais e raciais (ADI 3330); (ix) vedação ao nepotismo (ADC 12/DF e Súmula no 13); (x) não-recepção da Lei de Imprensa (ADPF 130/DF). A lista poderia prosseguir indefinidamente, com a identificação de casos de grande visibilidade e repercussão, como a extradição do militante italiano Cesare Battisti (Ext 1085/Itália e MS 27875/DF), a questão da importação de pneus usados (ADPF 101/ DF) ou da proibição do uso do amianto (ADI 3937/SP). Merece destaque a realização de diversas audiências públicas, perante o STF, para debater a questão da judicialização de prestações de saúde, notadamente o fornecimento de medicamentos e de tratamentos fora das listas e dos protocolos do Sistema Único de Saúde (SUS)."

26 "Juízes e membros dos tribunais não são agentes públicos eleitos. Sua investidura não tem o batismo da vontade popular. Nada obstante isso, quando invalida atos do Legislativo ou do Executivo ou impõe-lhes deveres de atuação, o Judiciário desempenha um papel que é inequivocamente político. Essa possibilidade de as instâncias judiciais sobreporem suas decisões às dos agentes políticos eleitos [...] Ao lado dessas, há, igualmente, críticas de cunho ideológico, que veem no Judiciário uma instância tradicionalmente conservadora das distribuições de poder e de riqueza na sociedade. Nessa perspectiva, a judicialização funcionaria como uma reação das elites tradicionais contra a democratização, um antídoto contra a participação popular e a política majoritária. [...] Cabe aos três Poderes interpretar a Constituição e pautar sua atuação com base nela. Mas, em caso de divergência, a palavra final é do Judiciário. [...] Capacidade institucional envolve a determinação de qual Poder está mais habilitado a produzir a melhor decisão em determinada matéria. Temas 
tinentes de que o papel do STF está na proteção e promoção dos direitos fundamentais, além de resguardar as regras do jogo democrático, sempre dar-se-á a favor da democracia (BARROSO, 2012, p. 14), apresenta-se um pouco tendenciosa. Ademais, verificando a própria composição do CNJ, nota-se claramente a influência dos demais Poderes no órgão responsável pelo controle da atuação administrativa e financeira do Poder Judiciário (artigo 103 da CR/1988). Aplicando-se uma metodologia simples por prerrogativa de nomeação da autoridade que compõe o $\mathrm{CNJ}^{27}$, é possível constatar que os Poderes Executivo e Legislativo assumem um poder real de influência na composição do Conselho em mais de 50\% (cinquenta por cento). Conforme o Gráfico 2, que representa os "votos de influência" na composição do órgão ${ }^{28}$ :

envolvendo aspectos técnicos ou científicos de grande complexidade podem não ter no juiz de direito o árbitro mais qualificado, por falta de informação ou de conhecimento específico. Também o risco de efeitos sistêmicos imprevisíveis e indesejáveis podem recomendar uma posição de cautela e de deferência por parte do Judiciário. O juiz, por vocação e treinamento, normalmente estará preparado para realizar a justiça do caso concreto, a microjustiça, sem condições, muitas vezes, de avaliar o impacto de suas decisões sobre um segmento econômico ou sobre a prestação de um serviço público. [...] Na outra face da moeda, a transferência do debate público para o Judiciário traz uma dose excessiva de politização dos tribunais, dando lugar a paixões em um ambiente que deve ser presidido pela razão. No movimento seguinte, processos passam a tramitar nas manchetes de jornais - e não na imprensa oficial - e juízes trocam a racionalidade plácida da argumentação jurídica por embates próprios da discussão parlamentar, movida por visões políticas contrapostas e concorrentes." (BARROSO, 2012, p. 10-13).

${ }^{27}$ Exemplifica-se: Conforme a leitura do art. 103-B, inciso XIII da C/R88, serão dois cidadãos de notável saber jurídico, escolhidos um pela Câmara dos Deputados (Poder Legislativo) e outro pelo Senado Federal (Poder Legislativo), a compor o CNJ. Conferindo ao Poder Legislativo, portanto, dois votos. A mesma norma constitucional em seu art. V, determina que um desembargador, escolhido pelo STF, deverá, também, compor o CNJ. Porém, como os desembargadores são nomeados pelos Governadores de seus respectivos Estados, esta composição possui como pontuação um voto de influência para o Poder Executivo e outro para o Poder Judiciário. Por fim e para esclarecer qualquer dúvida quanto à metodologia, tem-se o caso do Presidente do STF. Como visto, compete ao Poder Executivo nomear e ao Poder Legislativo aprovar, conferindo a cada poder um voto, nesse ínterim, uma vez que o Poder Judiciário não exerce nenhuma influência na composição do STF.

${ }^{28}$ Conforme se demonstrou, os desembargadores são nomeados por seus respectivos Governadores, importando a ingerência do Poder Executivo e o seu respectivo voto, com 


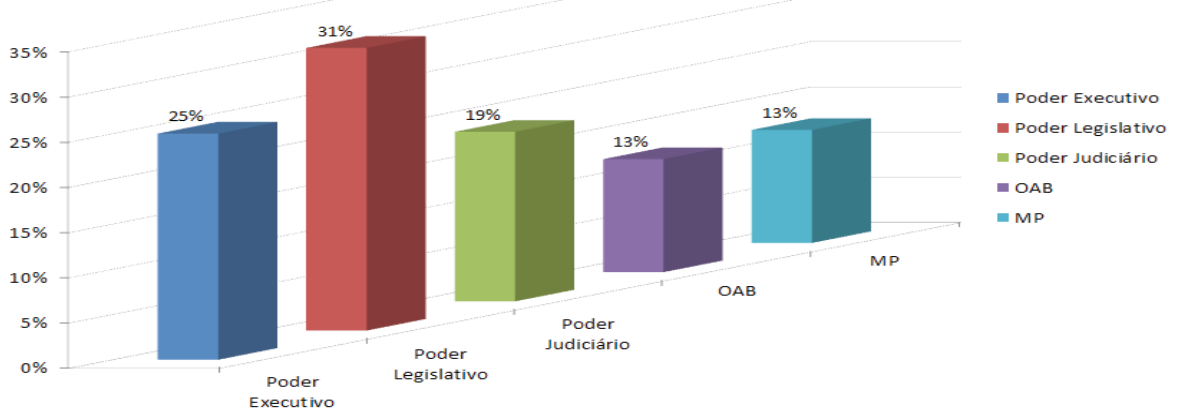

Gráfico 2: Voto de influência na composição do CNJ (2015)

Fonte: Elaborado pelos autores deste artigo

Em suma, longe de buscar a confirmação de uma tese de que a forma como se processa a escolha dos ministros do STF possa prejudicar a aplicação da Justiça, o que se verifica é que sob o prisma das regras de governança corporativa, apresentados na primeira parte do trabalho, tal método não corresponde às melhores práticas. A aprovação política a que são submetidos os candidatos a ministros, corresponde na necessidade de composição de alianças com o Poder Executivo, uma vez que com a maioria no Congresso, conseguiria compor a CCJ, com aliados que jamais iriam "reprovar" um candidato indicado pelo Chefe do Poder Executivo.

Nomear aqueles que irão proferir decisões com naturezas duplas (política e jurídica) é uma forma sucinta de intervir na própria decisão. Escolher os próximos, aumentar a sua influência com aqueles que detêm o poder, configura-se detrimento da independência e, em que a independência encontra-se comprometida, o conflito de interesses estará presente. Tais desenhos não são de exclusividade do STF, verifica-se o mesmo nos tribunais administrativos, como os Tribunais de Contas da União, dos Es-

exceção do procedimento de nomeação dos ministros do STF, tem-se que eles, do STJ e do TST seguem a mesma sistemática, sendo livremente nomeados pelo Presidente da República e, por via de regra, sabatinados e aprovados no Senado Federal (art. 104 e 111A da CR/1988). 
tados e dos Municípios, na nomeação dos desembargadores de justiça dos Estados, incluindo a composição do próprio Ministério Público (artigo $128, \S 1^{\circ}$, da CR/1988), citando apenas alguns. A influência política (leia-se, conflito de interesses) é um fator de real complicação à democracia e à construção de um verdadeiro estado democrático de direito. Portanto, mais do que válidas as advertências de Facchini Neto (2009) ao demonstrar que para a Espanha de Franco, pouco importava a suposta independência dos magistrados da instância originária, uma vez que o essencial era o domínio das instâncias superiores ${ }^{29}$. Apesar do avanço no campo da estrutural, o Brasil ainda tem muito o que avançar na questão de governança e desenvolvimento sustentável como forma de, além de dar transparência à gestão e às contas públicas, minimizar os conflitos de interesse envolvendo as questões e discussões, seja de ordem jurídica, econômica, política, social e etc. Dessa maneira:

Uma ampla concepção de desenvolvimento requer, obrigatoriamente, que o Estado esteja presente tanto na economia quanto na sociedade, integrado com os demais atores sociais para que seja possível alcançar os objetivos desenvolvimentistas. Assim, liberdade passa, então, a representar a capacidade crítica e consciente de o indivíduo existir na sociedade em relação à atividade institucional. Mais do que isso, a sustentabilidade requer, além de uma orientação individual e consciente, a firmação de responsabilidades objetivas e públicas, cujo sentido atinja à universalidade, enquanto processo integral de firmação de um contexto seguro e possível para as gerações futuras. (ALMEIDA; ENGELMANN, 2010, p. 24)

Salienta-se que a discussão sobre a composição do STF tem íntima relação com o princípio, atualmente simbólico, do desenvolvimento sustentável, não aplicável apenas ao direito ambiental. Afirma-se isso com base em Almeida e Araújo (2013, p. 11-51) que concluíram:

29 ،[...] Na Espanha de Franco, por exemplo, refere-se que a magistratura ordinária era relativamente imparcial e infensa a influencias políticas - salvo o órgão de cúpula do judiciário espanhol. De fato, a corte suprema era controlada pelo General Franco. Isso era o quanto bastava para que o regime obtivesse decisões favoráveis naqueles aspectos que realmente interessavam, em ultima instancia." (FACCHINI NETO, 2009, p. 125-127, grifo nosso). 
[...] que é possível admitir o desenvolvimento sustentável como instituto de direito constitucional, classificando-o como princípio fundamental de força normativa superior, aplicável para a obtenção de conclusões jurídicas vinculantes de todas as práticas do Estado e da sociedade, sempre guardando a ideia do poder-dever do primeiro para com a efetividade das propostas jurídicas e concretização finalística da ideologia social adotada pela carta constitucional vigente. $\mathrm{O}$ ordenamento jurídico brasileiro tem acompanhado e absorvido muitas dessas propostas, prevendo, ainda que implicitamente, o desenvolvimento sustentável como um princípio de natureza fundamental. (ALMEIDA; ARAÚJO, 2013, p. 46) ${ }^{30}$

Portanto, o desenvolvimento sustentável deve ser interpretado ampliativamente, como modo de garantir os direitos fundamentais e sociais $^{31}$, incluídos neles a própria guarda da Constituição que é assegurada pelos ministros do STF, permitindo o bem-estar social ${ }^{32}$ e a dignidade da pessoa humana.

\footnotetext{
${ }^{30}$ Isso quer dizer que o desenvolvimento sustentável deve ser ampliado, não se restringindo mais à compatibilização entre o meio ambiente e as atividades econômicas da sociedade, para ser compreendido como desenvolvimento socialmente includente, economicamente sustentado e ambientalmente sustentável, ante as dimensões básicas e essenciais da sociedade. Nesse sentido, verifica-se que o projeto do desenvolvimento sustentável verdadeiramente se presta a harmonizar os direitos fundamentais constitucionalizados do desenvolvimento econômico, do meio ambiente sadio e, mais do que isso, resta como princípio constitucional fundamental por conta da perfeita congruência de seus contornos conceituais com a ideologia constitucional do bem-estar social, cultural e ético (ALMEIDA; ARAÚJO, 2013, p. 45).

${ }^{31}$ Em sentido equivalente, “[...] a aplicação do Princípio do Desenvolvimento Sustentável não encontra efetivação na forma como o Judiciário faz a sua aplicação, na medida em que os possíveis significados do princípio, encontrados tanto na Constituição brasileira quanto na legislação infraconstitucional, pressupõem uma sustentação mais ampla, disposta a efetivar não só a dimensão ambiental, mas também os direitos fundamentais e sociais." (ALMEIDA; ARAÚJO, 2013, p. 15).

32 A previsão constitucional do princípio do desenvolvimento sustentável foi assim indicada: "As questões econômicas e ambientais englobam o conjunto de direitos humanos e por isso são tidas como de cunho social na atual Constituição, não podendo tais dimensões ficarem excluídas do conjunto de valores a serem considerados na contemplação do Direito Constitucional. Nessa perspectiva, ao se estudar o objeto de tutela ambiental, preconizado pelo artigo 225 da Constituição Federal de 1988, o qual
} 
De maneira que o desenvolvimento sustentável aparece como novo paradigma de atuação estatal. Ele deverá respeitar as dimensões da locução ambiental sob pena de ferir o artigo 225 da CR/88. Desse modo, os pilares clássicos e os modernos estão inseridos no texto constitucional de forma dispersa.

A concepção clássica do termo agrega as dimensões econômicas, sociais e ambientais, sendo que a tomada de decisão do ator responsável deve observância a essas dimensões. Caso o ator tome uma decisão com base apenas no argumento econômico, não estará configurada uma interpretação sustentável da decisão do agente político.

A dimensão ambiental foi a responsável pela criação do termo. A mudança provocada pela Estocolmo 1972 e os encontros posteriores, obrigaram essa nova forma de pensar o mundo. Ocorre que tais pilares não seriam suficientes para enfrentar o dilema proposto por este estudo. Portanto, serão utilizadas novas dimensões ${ }^{33}$ que foram tratadas em trabalhos posteriores.

A dimensão social, via de regra, é entendida como a dimensão responsável por combater a desigualdade social. Segundo Almeida e Araújo (2013), a função desse pilar "[...] é construir uma civilização com maior equidade na distribuição de renda e de bens, de modo a reduzir o abismo entre os padrões de vida dos ricos e dos pobres." (ALMEIDA; ARAÚJO, 2013, p. 28). A dimensão ética, segundo Freitas (2011, p. 57-60), trata do dever de fraternidade dentro da espécie e no relacionamento com as de-

anuncia o direito ao meio ambiente ecologicamente equilibrado, pode-se afirmar que o direito protegido nesta seara deve ser a síntese havida entre a qualidade do meio ambiente em função da apropriação dos recursos naturais como meio de sobrevivência do homem, representado pela expressão constitucional “[...] desenvolvimento sustentável”, e portanto a Carta da República de 1988 e toda a legislação infraconstitucional passaram a ser informadas por esses objetos acolhidos, como forma de garantir sua observância, a fim de elevar tais elementos à categoria de valores, dentro de um sistema integrado. Observa-se ainda que tal compatibilização deve acontecer tendo em vista a matriz econômica liberal acolhida pelo nosso Estado de Direito, uma vez que dentro os princípios fundamentais da República Federativa do Brasil está a livre iniciativa, preconizada no artigo $1^{\circ}$, inciso IV e reafirmada nos artigos $5^{\circ}$, incisos XIII, XXII e XXIII, 170, incisos I a IX da Carta Constitucional." (ALMEIDA; ARAÚJO, 2013, p. 19-20).

33 Para aprofundamentos nas dimensões do desenvolvimento sustentável, ver Freitas (2011, p. 53-70). 
mais. $\mathrm{O}$ indivíduo deve ser integrado à comunidade, à sociedade e esta à universalidade. $\mathrm{O}$ dever fraterno deve preponderar nas condutas sociais, impedindo ações puramente egoísticas e que visem o mal-estar dos demais.

Ora, a forma de composição do STF, por nomeação, por via de regra, causa no mínimo prejuízo à mitigação do conflito de interesses, pois, uma vez nomeados, a independência é influenciada e as decisões podem ser por interesses distintos daqueles da competência da organização e que se busca alcançar. Ressalta-se que esta afirmação encontra-se inserida no contexto da governança corporativa.

Por óbvio que existem várias discussões envolvendo a politização dos tribunais (administrativos e mesmos o judiciais), mas o que, na verdade e no mínimo, causa estranheza às boas práticas da governança corporativa, é a indicação e nomeação daqueles que irão analisar as contas públicas e por muitas vezes os próprios agentes públicos (incluindo aqui, os senadores, deputados federais e estaduais, vereadores, governadores, presidente e demais agentes políticos).

O conflito de interesses, pelo menos no âmbito potencial, é muito real no modelo adotado pela CR/1988, uma vez que presente a constante da parte relacionada, nos órgãos julgadores brasileiros, dentre outros. A constatação de tal modelo insurge na necessidade de uma discussão acerca da atual sistemática de nomeação dos cargos de ministros não somente do STF, mas de todo o Poder Judiciário quiçá de toda Administração Pública. O que se verifica, na verdade, é uma extensa e poderosa influência do partido majoritário (em sentido amplo, envolvendo as coligações, base aliada etc.) na composição dos tribunais superiores como forma de facilitar a aprovação de suas medidas, comprometendo a insurgência dos demais, sendo que a independência dos órgãos superiores é fortemente comprometida em prol da aprovação dos "aliados".

\section{Conclusão}

O processo de sabatina para a escolha de ministros do STF possui uma natureza predominantemente política. O notório saber jurídico, re- 
quisito constitucional é deixado à margem e a arguição, momento em que os agentes políticos apresentariam suas questões, cede lugar aos discursos políticos, tornando público o voto que a prima facie deveria ser secreto. A despeito da discussão legislativa acerca da mudança envolvendo as regras de nomeação ao cargo de ministro do STF, tais regras não se assemelham àquelas destinadas à Suprema Corte Britânica, conferindo ao procedimento de sabatina, uma natureza pró-forma, uma "disputa de cartas marcadas".

Esta preponderância política na indicação, escolha e aprovação de ministros do STF, leva a conclusão de que o acesso aos tribunais superiores brasileiros, em função dos princípios de governança corporativa, não se adéqua as melhores práticas, e muito menos à sustentabilidade. Nomear e aprovar aqueles que conferirão legalidade aos atos emanados deixa clara a existência do conflito de interesses, tanto daqueles que nomeiam (tendo em vista o interesse de escolher o candidato que mais irá colaborar com o projeto de governo, não de Estado), quanto dos nomeados (tendo em vista o desejo de compor a mais alta corte de justiça brasileira). Se na prática, muitas vezes, tal conclusão não se verifica, no campo da tese, ao menos o desenho constitucional mostra-se pernicioso.

Com isso, o direito constitucional é a sede e assume o papel de guardião das políticas públicas de sustentabilidade, levando em consideração os interesses legítimos das gerações futuras. É preciso valorizar as atividades típicas do Estado, não de governo (que são aquelas que permanecem quando os mandatos políticos terminam), o que não é observado na atual tomada de posse dos ministros do STF, pelo menos até que os nomeantes não estejam mais governando.

\section{Referências}

ALMEIDA, Alessandra Bagno F. R. de; ARAÚJO, Marinella Machado. O direito ao desenvolvimento sustentável e a dimensão simbólica de sua aplicação. In: REZENDE, Élcio Nacur; CARVALHO, Valdênia Geralda de (Org.). Direito ambiental e desenvolvimento sustentável: edição comemorativa dos dez anos da Escola Superior Dom Helder Câmara. 
Belo Horizonte: Escola Superior Dom Helder Câmara ESDHC, 2013. p. 11-51.

ALMEIDA, Ana Paula de; ENGELMANN, João Gilberto. Direito e sustentabilidade: perspectivas de uma geração livre e possível. Revista Veredas do Direito, Belo Horizonte, v. 7, n. 13/14, p. 11-25, jan.-dez. 2010.

BARROSO, Luís Roberto. Constituição, democracia e supremacia judicial: direito e política no Brasil contemporâneo. Revista da Faculdade de Direito da UERJ, Rio de Janeiro, v. 2, n. 21, p. 2-50, jan./jun. 2012. Disponível em: <file://C:/Users/braulio.pighini/ Downloads/1794-12752-2-PB.pdf>. Acesso em: 13 fev. 2015. BRASIL. Constituição da República Federativa do Brasil, de 5 out. 1988, Diário Oficial da União. Brasília, DF, 5 out. 1988. Disponível em: <http://www.planalto.gov.br/ccivil_03/constituicao/ constituicaocompilado.htm>. Acesso em: $10 \mathrm{dez} . \overline{-} 014$.

BRASIL. Lei Complementar n. 73, de 10 fevereiro 1993. Institui a Lei Orgânica da Advocacia-Geral da União e dá outras providências. Diário Oficial da União, Brasília, DF, 11 fev. 1993. Disponível em: <http://www. planalto.gov.br/ccivil_03/leis/lcp/lcp73.htm>. Acesso em: 13 fev. 2015.

BRASIL. Lei Complementar n. 35, de 14 de março 1979. Dispõe sobre a Lei Orgânica da Magistratura Nacional. Diário Oficial da União, Brasília, DF, 14 mar. 1979. Disponível em: <http://www.planalto.gov.br/ ccivil_03/leis/lcp/lcp35.htm>. Acesso em: 5 fev. 2015.

BRASIL. Lei n. 5.869, de 11 de janeiro 1973. Institui o Código de Processo Civil. Diário Oficial da União, Brasília, DF, 17 jan. 1973. Disponível em: <http://www.planalto.gov.br/ccivil_03/leis/ 15869compilada.htm>. Acesso em: 13 fev. 2015.

BRASIL. Lei n. 9.868, de 10 de novembro de 1999. Dispõe sobre o processo e julgamento da ação direta de inconstitucionalidade e da ação declaratória de constitucionalidade perante o Supremo Tribunal Federal. Diário Oficial da União, Brasília, DF, 11 set. 1999. Disponível em: $<$ http://www.planalto.gov.br/ccivil_03/leis/19868.htm>. Acesso em: 9 fev. 2015. 
BRASIL. Conselho Nacional de Justiça. Resolução n. 106, de 6 abril 2010. Dispõe sobre os critérios objetivos para aferição do merecimento para promoção de magistrados e acesso aos Tribunais de $2^{\circ}$ grau. Diário da Justiça, Brasília, DF, 9 abr. 2010. Disponível em: <http:/www.cnj. jus.br/atos-administrativos/12224:resolucao-no-106-de-06-de-abrilde-2010>. Acesso em: 9 fev. 2015.

BRASIL. Constituição dos Estados Unidos do Brasil, de 5 nov. 1937, Diário Oficial da União, Brasília, DF, 10 nov. 1937. Disponível em: $<$ http://www.planalto.gov.br/ccivil_03/Constituicao/Constituicao37. htm\#art96p>. Acesso em: 9 fev. 1937.

BRASIL. Senado Federal. Regimento Interno do Senado Federal. Diário Oficial da União, Brasília, $1^{\circ}$ fev. 2011. Disponível em: <http://www. senado.gov.br/legislacao/regsf/RegimentoInternoSF_alt_2014_versao PLE.pdf $>$. Acesso em: 9 fev. 2015.

CAMPOS, Helena Nunes. Princípio da proporcionalidade: a ponderação dos direitos fundamentais. Caderno de Pós-Graduação em Direito Político e Econômico, São Paulo, v. 4, n. 1, p. 23-32, 2004. Disponível em: <http://www.mackenzie.br/fileadmin/Pos_Graduacao/Mestrado/ Direito_Politico_e_Economico/Cadernos_Direito/Volume_4/02.pdf $>$. Acesso em: 9 fev. 2015.

CAPPELLETTI, Mauro. Juízes legisladores? Porto Alegre: S. A. Fabris, 1999.

CRETELLA JÚNIOR, JOSÉ. Comentários à Constituição de 1988. Rio de Janeiro: Forense Universitária, 1992. v. 4.

DAMASCENO, João Batista. Justiça como poder: judicialização da política, politização da justiça e pessoalização da jurisdição. 2005. 210 f. Dissertação (Mestrado) - UFRJ/IFCS - Programa de Pós-Graduação em Ciência Política, Rio de Janeiro. 2005.' Disponível em: <http://www. dominiopublico.gov.br/download/teste/arqs/cp028276.pdf $>$. Acesso em: 7 fev. 2015.

FERNANDES, Ricardo Vieira de Carvalho. Influências extrajurídicas sobre a decisão judicial: determinação, previsibilidade e objetividade do direito brasileiro. 2013. 352 f. Tese (Doutorado em Direito Estado e 
Constituição) - Universidade de Brasília (UnB), Faculdade de Direito, Programa de Pós-Graduação em Direito, Brasília, DF. 2013.

FREITAS, Juarez. Sustentabilidade: direito ao futuro. Belo Horizonte: Fórum, 2011.

GARAPON, Antoine. O juiz e a democracia: o guardião das promessas. 2. ed. Rio de Janeiro: Revan, 2001.

HAMILTON, Alexander; MADISON, James; JAY, John. O federalista. Tradução de Heitor Almeida Herrera. Brasília, DF: Universidade de Brasília, 1984.

LEAL, Victor Nunes. Coronelismo, enxada e voto o município e o regime representativo no Brasil. Rio de Janeiro: Nova Fronteira, 1997.

MACHADO, Diana Soares. A politização do Supremo Tribunal Federal diante do mecanismo de escolha de seus ministros. 2007. $64 \mathrm{f}$. Trabalho de Conclusão de Curso (Especialização em Instituições e Processos Legislativo) - Câmara dos Deputados - Centro de Formação, Treinamento e Aperfeiçoamento, Brasília, DF. Disponível em: < file://C:/ Users/braulio.pighini/Downloads/politizacao_supremo_machado\%20(2). pdf>. Acesso em: 9 fev. 2015.

MACCALÓZ, Salete. O Poder Judiciário, os meios de comunicação e opinião pública. Rio de Janeiro: Lumen Juris, 2002.

MENGARDO, Bárbara. Cadeira vazia causa adiamento de julgamentos no Supremo. Valor Econômico, São Paulo, 9 fev. 2015. Legislação \& Tributos, E1.

MORAES, Alexandre de. Jurisdição constitucional e tribunais constitucionais. São Paulo: Atlas, 2000.

MOTTA, Valdo Cruz Severino. STF não pode se converter em uma "corte bolivariana", defende Gilmar. Folha de São Paulo, Brasília, DF, 3 nov. 2014. Disponível em: <http://www1.folha.uol.com.br/ poder/2014/11/1542317-o-stf-nao-pode-se-converter-em-uma-cortebolivariana.shtml>. Acesso em: 7 fev. 2015. 
OLIVEIRA, Fabiana Luci de. Justiça, profissionalismo e política: o STF e o controle da constitucionalidade das leis no Brasil. Rio de Janeiro: FGV, 2011.

PAES, Taíse Sossai. A influência do processo de escolha dos ministros da Suprema Corte na judicialização da política: uma análise empírica do procedimento da sabatina dos indiciados para o Supremo Tribunal Federal. 2011. 78 f. Dissertação (Mestrado Profissional em Poder Judiciário) - Fundação Getúlio Vargas - Escola de Direito do Rio de Janeiro. 2011. Disponível em: <http://bibliotecadigital.fgv.br/dspace/ bitstream/handle/10438/8572/DMPPJ\%20-\%20TAISE\%20SOSSAI. pdf? sequence $=1 \&$ isAllowed $=\mathrm{y}>$. Acesso em: 14 jan. 2015Q

PAIXÃO, Leonardo André. A função política do Supremo Tribunal Federal. 2007. 258 f. Tese (Doutorado em Direito do Estado) Faculdade de Direito da Universidade de São Paulo. 2007. Disponível em: <file://C:/Users/braulio.pighini/Downloads/PAIXAO_Funcao_ Politica_do_STF\%20(2).pdf>. Acesso em: 9 fev. 2015.

RECONDO, Felipe. Ministra do STJ diz que a escolha de candidatos, com pouco tempo de magistratura, é "resultado de conchavos" no tribunal. Estadão, Brasília, DF, 22 nov. 2009. Disponível em: $<$ http:// www.estadao.com.br/noticias/geral,grupo-elege-pessoas-amigas-comlistas-fechadas,470184>. Acesso em: 9 fev. 2015.

SCHWARTZ, Bernard. Direito constitucional americano. Rio de Janeiro: Forense, 1955.

SILVA, Jose Afonso da. Curso de direito constitucional positivo. 34. ed. São Paulo: Malheiros, 2011.

SPECK, Bruno Wilhelm. Caminhos da transparência: análise dos componentes de um sistema nacional de integridade. São Paulo: UNICAMP, 2002.

TAVARES FILHO, Newton. Democratização do processo de nomeação dos ministros do Supremo Tribunal Federal. Brasília, DF: Câmara dos Deputados, 2006. 
Magno Federici Gomes é pós-doutor em Direito Público e Educação pela Universidade Nova de Lisboa-Portugal, pós-doutor em Direito Civil e Processual Civil, doutor em Direito e mestre em Direito Processual pela Universidad de Deusto-Espanha, mestre em Educação pela PUC Minas, professor do Mestrado Acadêmico em Direito Ambiental e Sustentabilidade na Escola Superior Dom Helder Câmara, professor adjunto da PUC Minas, professor titular licenciado da Faculdade de Direito Arnaldo Janssen e advogado sócio do escritório Raffaele \& Federici Advocacia Associada.

E-mail: federici@pucminas.br.

Endereço profissional: Pontifícia Universidade Católica de Minas Geiras, Departamento de Direito, Rua Walter Ianni, n. 255, bloco G, São Gabriel, Belo Horizonte, MG. CEP: - 31980-110.

Bráulio Chagas Pighini é mestre em Direito Político e Econômico pela Universidade Mackenzie, pós-graduado em Direito dos Contratos pela Fundação Getúlio Vargas/SP, pós-graduado em Direito do Trabalho e Previdenciário pela UGF/RJ, graduado em Direito pela Pontifícia Universidade Católica de Minas Gerais, e advogado.

E-mail:brauliopighini@hotmail.com.

Endereço Profissional: Universidade Presbiteriana Mackenzie, Ed. João Calvino, Rua da Consolação, n. 930, Consolação, São Paulo, SP. CEP: 01302-907. 